\title{
Analisis Kerentanan Tanah Longsor Menggunakan Metode Frequency Ratio di Kabupaten Bandung Barat, Jawa Barat
}

\section{Landslide Vulnerability Analysis Using Frequency Ratio Method in West Bandung Regency, West Java}

\author{
Danang Dwi Nugroho*1, Hary Nugroho \\ ${ }^{1,2}$ Jurusan Teknik Geodesi, Fakultas Teknik Sipil dan Perencanaan, Institut Teknologi Nasional, Bandung, Indonesia \\ *Korespondensi penulis: dwinugrohodanang27@gmail.com
}

Diterima: 30082020; Diperbaiki: 29092020; Disetujui: 08102020; Dipublikasi: 13112020

\begin{abstract}
Abstrak: Kabupaten Bandung Barat adalah salah satu kabupaten di Provinsi Jawa Barat dengan potensi gerakan tanah yang tinggi, sehingga sangat rentan terhadap kejadian tanah longsor. Hal ini dipicu oleh kondisi topografi yang beragam dan memungkinkan kejadian ini akan terus terjadi di masa depan. Salah satu metode yang sering digunakan dalam pemetaan kerentanan tanah longsor adalah frequency ratio. Metode ini bertujuan untuk mengidentifikasi wilayah rentan tanah longsor berdasarkan data kejadian longsor di masa lalu yang pada gilirannya dapat dijadikan parameter untuk mitigasi bencana longsor. Metode ini diaplikasikan menggunakan aplikasi GIS dengan data-data sekunder seperti DEM, peta tutupan lahan, data curah hujan, peta geologi, dan peta klasifikasi tanah. Data tersebut merepresentasikan faktor-faktor yang memengaruhi tanah longsor yaitu kemiringan lereng, elevasi, arah kemiringan lereng, tutupan lahan, curah hujan, jenis tanah, jarak sesar, dan batuan geologi. Faktorfaktor tersebut ditumpangtindihkan menjadi peta raster $(20 \mathrm{~m})$ dan menghasilkan nilai frequency ratio. Nilai tersebut diklasifikasikan menjadi 5 zona kerentanan longsor yaitu tidak rentan, sedikit rentan, cukup rentan, rentan, dan sangat rentan. Hasil penelitian ini menunjukkan terdapat 7 faktor pengkondisi tanah longsor yang memengaruhi kerentanan tanah longsor. Hasil uji akurasi ini menghasilkan peta kerentanan tanah longsor dengan nilai akurasi sebesar 79,7\% sehingga dapat diterapkan dalam upaya mitigasi tanah longsor.
\end{abstract}

Copyright () 2020 Geoid. All rights reserved.

\begin{abstract}
West Bandung regency is one of the districts in West Java Province with high potential for land movement, making it very vulnerable to landslide events. This is triggered by diverse topographic conditions and allows these events to continue to occur in the future. One of the methods often used in mapping landslide vulnerabilities is frequency ratio. This method aims to identify landslide-prone areas based on data on past landslide events that in turn can be used as parameters for landslide disaster mitigation. This method is applied using GIS application with secondary data such as DEM, land cover map, rainfall data, geological map, and land classification map. The data represents factors that affect landslides, namely slope, elevation, slope direction, land cover, rainfall, soil type, fault distance, and geological rocks. These factors are overlayed into raster maps $(20 \mathrm{~m})$ and produce frequency ratio values. These values are classified into 5 landslide vulnerability zones that are not vulnerable, slightly vulnerable, vulnerable enough, vulnerable, and highly vulnerable. The results of this study showed there are 7 factors of landslide conditioning that affect the vulnerability of landslides. This accuracy test resulted in a landslide vulnerability map with an accuracy value of $79.7 \%$ so that it could be applied in landslide mitigation efforts.
\end{abstract}

Kata kunci: frequency ratio; GIS; kerentanan tanah longsor; mitigasi

\section{Pendahuluan}

Berdasarkan kondisi geografis, geologis, maupun demografis, Indonesia dapat dikategorikan sebagai negara yang memiliki tingkat kerentanan yang tinggi terhadap terjadinya bencana alam. Hal ini disebabkan oleh pertemuan tiga lempeng besar dunia, yaitu Lempeng Indo-Australia, Lempeng Eurasia, dan Lempeng Pasifik. Interaksi antar lempeng tersebut membuat Indonesia termasuk dalam jalur pegunungan aktif (ring of fire) (Sadisun, 2005). Keberadaan jalur pegunungan aktif ini menyebabkan beberapa wilayah Indonesia, termasuk Provinsi Jawa Barat terbentuk pegunungan dan perbukitan dengan kemiringan lereng landai 
hingga curam. Kondisi tersebut menyebabkan Provinsi Jawa Barat memiliki potensi bencana alam khususnya tanah longsor. Salah satu kabupaten di Provinsi Jawa Barat yang memiliki potensi bencana tanah longsor yang tinggi adalah Kabupaten Bandung Barat. Menurut laporan dari Pusat Vulkanologi dan Mitigasi Bencana Geologi pada tahun 2018, di Kabupaten Bandung Barat telah terjadi 144 kejadian bencana longsor dalam kurun waktu 2009-2018 (PVMBG, 2018). Apabila dilihat dari kondisi topografi, Kabupaten Bandung Barat mempunyai dominasi kemiringan lereng yang curam dengan sebagian besar batuan andesit dan breksi andesit yang bersifat kedap air, dimana tanah mudah tererosi apabila berada di atas batuan tersebut (PUPR, 2015).

Sejalan dengan pendapat Arifin dkk (2006) bahwa "Longsor merupakan suatu bencana yang mengakibatkan kerugian cukup besar, baik berupa harta maupun korban jiwa. Walaupun kejadian longsor terjadi sesaat, akan tetapi secara jangka panjang dapat memengaruhi kehidupan masyarakat setempat." Oleh karena itu, penting sekali untuk dapat mengetahui potensi kerentanan tanah longsor di Kabupaten Bandung Barat ini. Potensi ini dapat diketahui melalui identifikasi daerah bencana tanah longsor yang pernah terjadi. Dalam identifikasi tersebut, kondisi fisik dan kondisi sosial membentuk beberapa keadaan terpenuhinya bencana tanah longsor. Arsyad (2010) mengemukakan bahwa tanah longsor dapat terjadi apabila tiga keadaan terpenuhi, yaitu (1) lereng yang cukup curam, (2) terdapat lapisan di bawah permukaan tanah yang kedap air dan lunak sebagai bidang luncur, dan (3) terdapat cukup air di dalam tanah, sehingga lapisan tanah tepat di atas lapisan kedap air menjadi jenuh. Peristiwa alam ini umumnya dapat terjadi pada wilayah yang mempunyai berbagai jalur pegunungan dan perbukitan.

Berdasarkan kondisi ini maka perlu dilakukan penelitian guna melakukan analisis wilayah rentan longsor. Penelitian ini dilakukan sebagai upaya untuk memberikan informasi tingkat pengaruh kelas dan faktor pengkondisi tanah longsor, dan gambaran wilayah-wilayah yang memiliki kerentanan terhadap tanah longsor serta sebagai upaya untuk memberikan informasi kepada pihak terkait, seperti pemerintah daerah, yang memiliki kewenangan dalam memberikan advice planning dalam pembangunan rumah atau kawasan perumahan.

Melihat fakta tersebut, teknologi SIG secara efektif dapat digunakan untuk mengembangkan inventarisasi tanah longsor, menganalisis distribusi spasial, dan menyusun peta kerentanan tanah longsor khususnya di Kabupaten Bandung Barat. Upaya mitigasi untuk mengurangi atau meminimalisir dampak akibat bencana tanah longsor dilakukan dengan cara memperbandingkan persediaan tanah longsor dengan faktor pengkondisi tanah longsor. Hubungan yang diturunkan antara inventaris tanah longsor dan faktor pengkondisi tanah longsor digunakan dalam penelitian Tien Bui dkk (2011), Conforti dkk (2012), dan Polykretis (2014) untuk mengembangkan peta kerentanan tanah longsor sehingga faktor pengkondisi tanah longsor yang paling signifikan dapat diketahui secara kuantitatif dan dapat digunakan sebagai langkah preventif mitigasi bencana tanah longsor.

\section{Data dan Metode}

Lokasi penelitian berada di Kabupaten Bandung Barat, Provinsi Jawa Barat yang terletak pada $06^{\circ} 41^{\prime}$ $07^{\circ} 19^{\prime}$ LS dan $107^{\circ} 22^{\prime}$ - $108^{\circ} 05^{\prime}$ BT seperti yang ditunjukkan pada Gambar 1. Kabupaten Bandung Barat memiliki luas wilayah $1.302,30 \mathrm{~km}^{2}$ yang terdiri dari 16 kecamatan. Data yang digunakan dalam penelitian ini, yaitu DEM Nasional, Peta Tutupan Lahan Tahun 2018, Riwayat Titik Longsor Tahun 2009-2018, Curah Hujan di 5 Titik Stasiun Klimatologi Jawa Barat, Peta Geologi Skala 1:100.000, Peta Raster Klasifikasi Tanah, dan Batas Administrasi. Keseluruhan data tersebut dikonversi menjadi data raster dengan resolusi seragam $(20 \mathrm{~m})$. Proses pelaksanaan penelitian meliputi konversi data vektor menjadi data raster, perhitungan class pixels setiap kelas dari masing-masing faktor pengkondisi tanah longsor, dan perhitungan frequency ratio seperti yang ditunjukkan pada Gambar 2. Adapun perhitungan frequency ratio dihitung dengan menggunakan persamaan 1 berikut ini: 
$\mathrm{FR}=\frac{C P / L P}{\sum C P / \sum L P}$

dimana $\mathrm{FR}=$ frequency ratio, $\mathrm{CP}=$ class pixel suatu kelas dalam faktor tertentu, $\mathrm{LP}=$ landslide pixel suatu kelas dalam faktor tertentu, $\mathrm{LP}=$ landslide pixel suatu kelas dalam faktor tertentu, $\sum \mathrm{CP}=$ jumlah class pixel suatu kelas dalam faktor tertentu, $\sum \mathrm{LP}=$ jumlah landslide pixel suatu kelas dalam faktor tertentu.

Hasil perhitungan frequency ratio yang telah didapat menjadi dasar perhitungan prediction rate. Sebelum mengetahui nilai prediction rate, sebelumnya dilakukan formula "=min" dan "=max" terhadap nilai frequency ratio. Kemudian, setelah mendapatkan hasil kedua formula tersebut dilakukan perhitungan prediction rate menggunakan persamaan 2 berikut ini:

$\mathrm{PR}=\frac{\operatorname{Max}-\operatorname{Min} F R}{(\operatorname{Max}-\operatorname{Min}) \operatorname{Min} F R}$

dimana $\mathrm{PR}=$ prediction rate, Max-Min $\mathrm{FR}=$ selisih nilai maksimum dan minimum frequency ratio pada faktor pengkondisi tanah longsor, (Max-Min) Min FR = nilai minimum dari selisih nilai maksimum dan minimum frequency ratio pada faktor pengkondisi tanah longsor.

Untuk proses uji validasi, digunakan metode analisis ROC (Receiver Operating Characteristics) yang mengikutsertakan sejumlah titik validasi. Metode ini adalah metode untuk mengukur kemampuan klasifikasi dalam menentukan threshold dari suatu model Mathew dkk (2014). Penentuan threshold tersebut dapat digambarkan dengan mengetahui luas area dari suatu model atau yang disebut Area Under Curve (AUC). Hasil akhir dari penelitian ini berupa faktor pengkondisi tanah longsor yang memengaruhi kerentanan tanah longsor, peta zonasi kerentanan tanah longsor, dan nilai akurasi dari penggunaan metode frequency ratio.

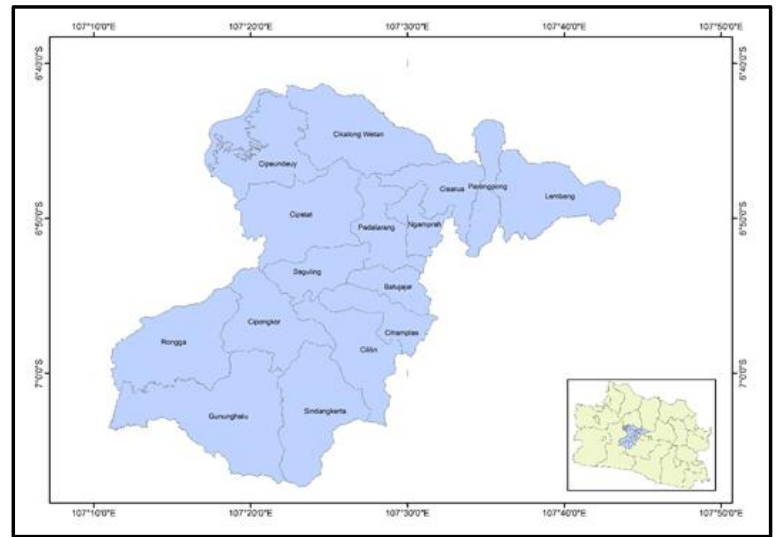

Gambar 1. Daerah Penelitian Kabupaten Bandung Barat



Gambar 2. Diagram Alir Metodologi Penelitian 


\section{Hasil dan Pembahasan}

Hasil dari penelitian ini diuraikan menjadi beberapa bagian, yaitu hasil pengaruh setiap kelas pada masingmasing faktor pengkondisi tanah longsor, hasil faktor pengkondisi tanah longsor yang dominan pada kerentanan tanah longsor, hasil zonasi kerentanan tanah longsor di Kabupaten Bandung Barat, dan hasil uji akurasi metode analisis ROC.

\section{Hasil Pengaruh Setiap Kelas Pada Masing-Masing Faktor Pengkondisi Tanah Longsor}

Setiap kelas pada masing-masing faktor pengkondisi tanah longsor mempunyai pengaruh terhadap kerentanan tanah longsor. Tingkat pengaruh setiap kelas tersebut terhadap kerentanan tanah longsor bergantung pada nilai frequency ratio yang dihasilkan.

\section{a. Kemiringan Lereng}

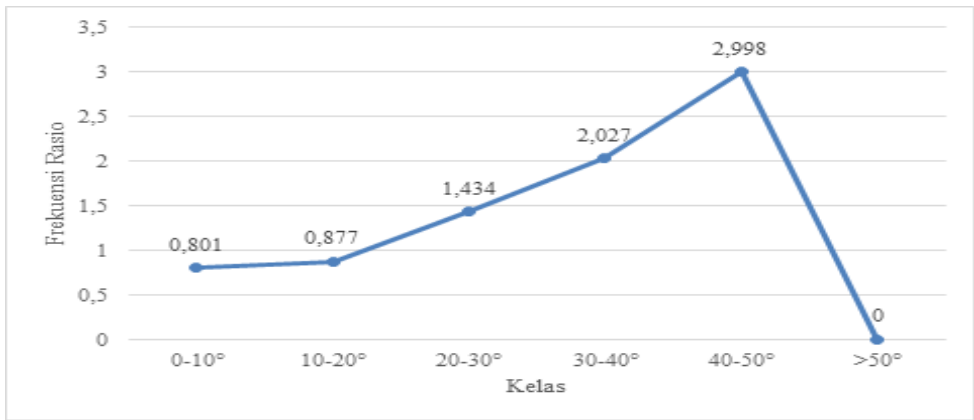

Gambar 3. Grafik Kumulatif Kemiringan Lereng

Berdasarkan Gambar 3 dapat diketahui bahwa pada faktor kemiringan lereng, kelas $20-30^{\circ}, 30-40^{\circ}$, dan $40-$ $50^{\circ}$ memiliki rasio $>1$ yang menunjukkan probabilitas tinggi terjadinya longsor, sedangkan kelas $>50^{\circ}$ hanya memiliki rasio 0 atau dapat dikatakan tidak ditemukan longsor. Hal ini disebabkan oleh dua hal, yaitu adanya kendala aksesibilitas pada kelas $>50^{\circ}$, atau karena adanya tutupan lahan berupa hutan yang mendominasi kelas kemiringan lereng ini. Direktorat Geologi dan Tata Lingkungan (2009) mengungkapkan bahwa keseimbangan lereng yang terganggu mengakibatkan perpindahan massa batuan dan massa tanah yang bergerak ke tempat lebih rendah. Oleh karena itu, tidak adanya longsor pada kelas $>50^{\circ}$ dikarenakan tutupan lahan mampu menjaga keseimbangan lereng yang baik.

\section{b. Elevasi}

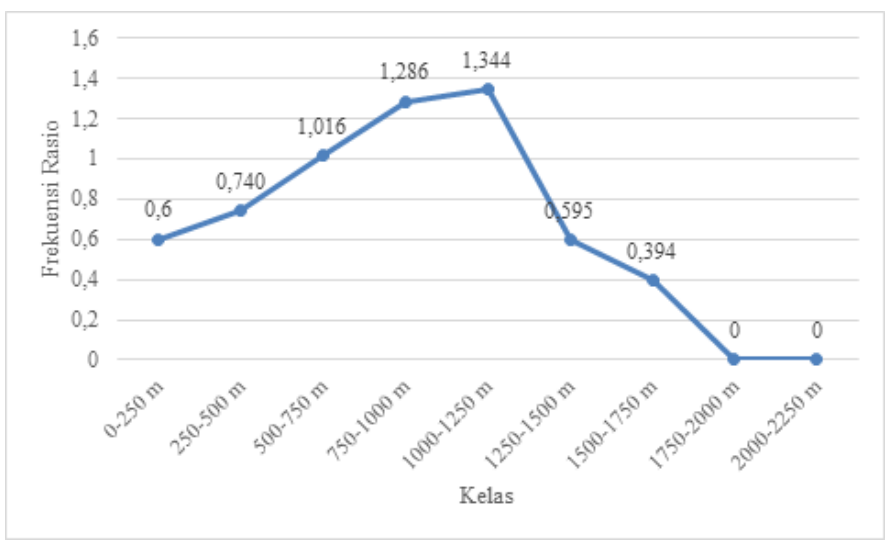

Gambar 4. Grafik Elevasi

Berdasarkan Gambar 4 dapat diketahui bahwa pada faktor elevasi terlihat frequency ratio mempunyai nilai semakin besar seiring dengan meningkatnya kelas elevasi. Namun, peningkatan tersebut berhenti pada kelas 
1000 - $1250 \mathrm{~m}$ dan diikuti dengan penurunan frequency ratio. Dalam hal ini, elevasi suatu daerah dapat dijadikan faktor pengkondisi tanah longsor karena pada elevasi yang tinggi secara umum mempunyai banyak lereng curam, meskipun pada beberapa daerah di dataran tinggi terdapat lereng landai (Gerrard, 1981). Dengan adanya hubungan elevasi dan kemiringan lereng, maka tren penurunan frequency ratio yang dimulai dari elevasi 1250 - $2250 \mathrm{~m}$ dapat disebabkan geoekologi yang masih seimbang.

\section{c. Arah Kemiringan Lereng}

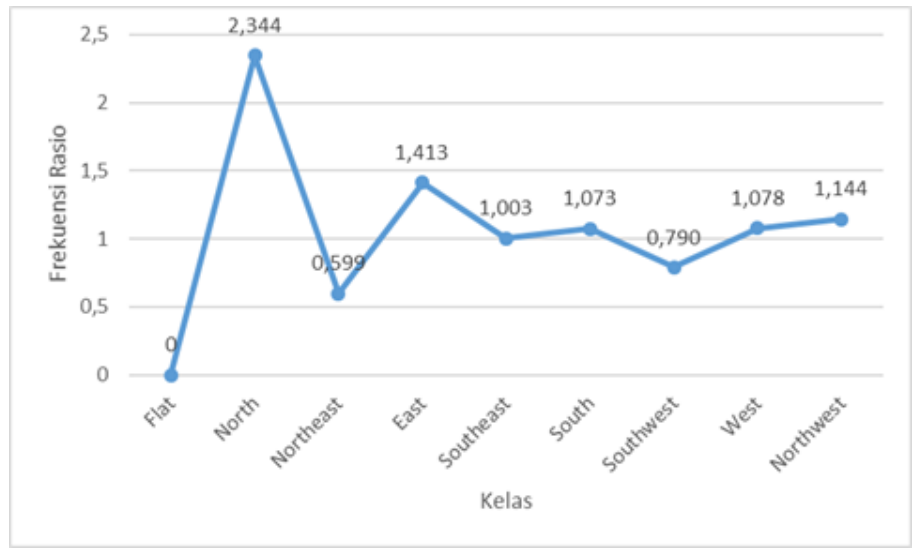

Gambar 5. Grafik Kumulatif Arah Kemiringan Lereng

Berdasarkan Gambar 5 dapat diketahui bahwa pada faktor arah kemiringan lereng, kelas utara mempunyai frequency ratio paling tinggi diantara kelas yang lain. Hal ini disebabkan karena topografi di daerah penelitian terdapat dataran tinggi di sebelah ujung timur, kemudian terdapat dataran rendah dan danau di sebelah ujung utara. Oleh karena itu, arah kemiringan lereng yang terbentuk sebagian besar didominasi oleh arah utara yang menghadap ke dataran rendah dan danau.

\section{d. Tutupan Lahan}

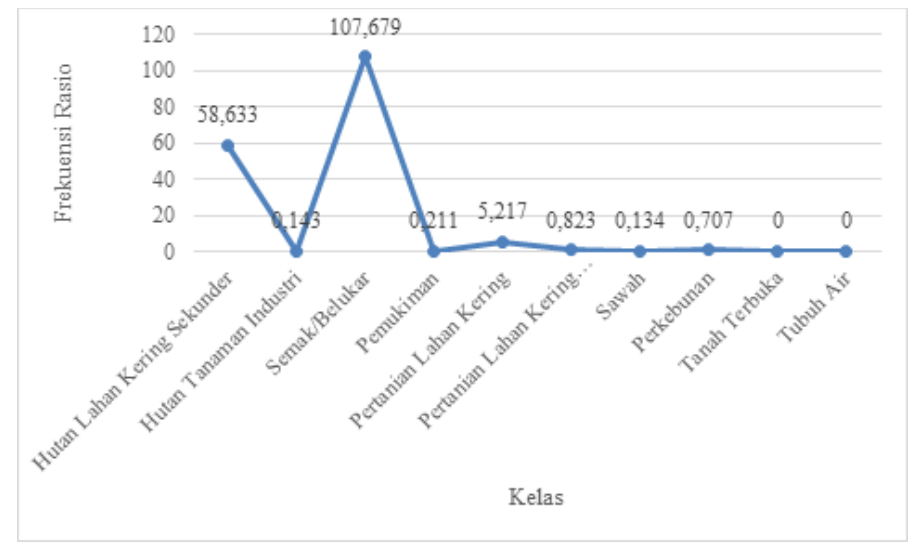

Gambar 6. Grafik Kumulatif Tutupan Lahan

Berdasarkan Gambar 6 dapat diketahui bahwa pada faktor tutupan lahan, kelas semak/belukar mempunyai frequency ratio paling tinggi diantara kelas-kelas pada semua faktor pengkondisi tanah longsor. Hal ini disebabkan karena sistem perakaran pada semak/belukar belum sanggup mengikat tanah. Hal serupa dapat terjadi pada kelas hutan lahan kering sekunder yang telah terintervensi oleh kegiatan manusia atau telah menampakkan bekas penebangan (alur dan bercak bekas tebang). Menurut Abe dan Ziemer (1991) akar tanaman dapat membantu menjaga stabilitas lereng bukit, melalui peningkatan kekuatan geser tanah. Oleh karena itu, kedua tutupan lahan tersebut perlu dibenahi terkait sistem akar tanamannya agar terbebas dari kejadian tanah longsor. 


\section{e. Curah Hujan}

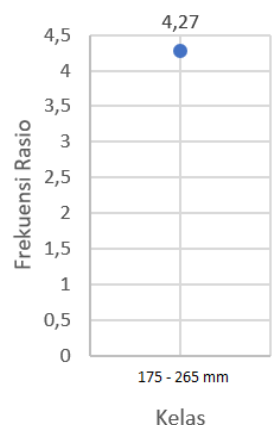

Gambar 7. Grafik Kumulatif Curah Hujan

Berdasarkan Gambar 7 dapat diketahui bahwa pada faktor curah hujan hanya terdapat satu kelas, yaitu 175 - $265 \mathrm{~mm}$. Hal ini disebabkan karena data yang digunakan (5 titik Stasiun Klimatologi) mempunyai jarak yang terlalu jauh dengan daerah penelitian, sehingga data tersebut dipaksakan untuk cover area. Apabila di dalam suatu daerah hanya memiliki satu kelas untuk diklasifikasikan, maka kelas tersebut tidak memiliki pengaruh yang signifikan terhadap kejadian tanah longsor (Corsini dkk, 2009).

\section{f. Jenis Tanah}

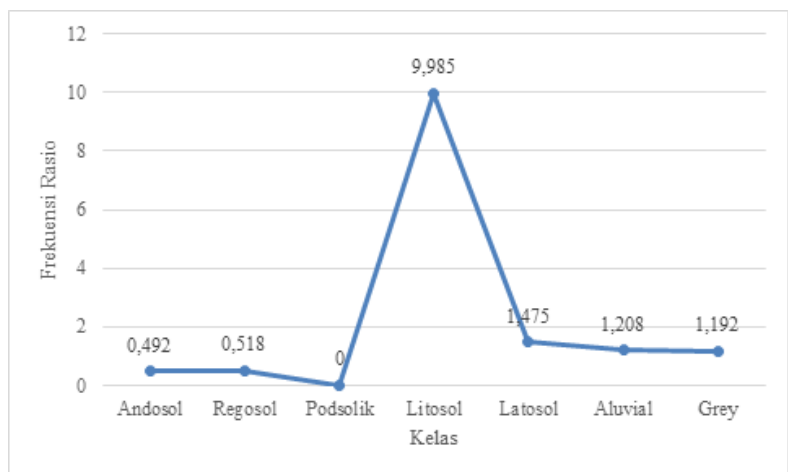

Gambar 8. Grafik Kumulatif Jenis Tanah

Berdasarkan Gambar 8 dapat diketahui bahwa pada faktor jenis tanah, kelas litosol merupakan kelas yang paling memengaruhi kejadian tanah longsor dengan nilai frequency ratio sebesar 9,985. Litosol didominasi oleh susunan batuan beku dan sedimen. Dari kondisi ini terlihat bahwa litosol peka terhadap erosi dan pelapukan yang memicu tempat peluncuran (Arsyad, 2010). Oleh karena itu, peluang terjadinya proses longsor di daerah ini cukup logis, dikarenakan bahan yang siap diluncurkan tersedia (solum tanah dalam) dan ditambah dengan kondisi topografi berupa dataran tinggi yang pada umumnya kaya dengan lereng terjal.

\section{g. Jarak Sesar}

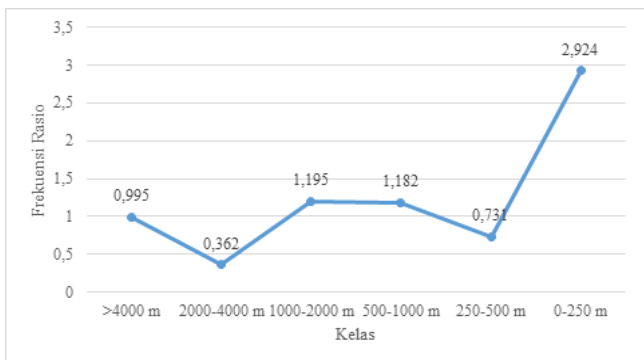

Gambar 9. Grafik Kumulatif Jarak Sesar 
Berdasarkan Gambar 9 dapat diketahui bahwa pada faktor jarak sesar, kelas $>4000$ m merupakan kelas yang paling memengaruhi kejadian tanah longsor dengan nilai frequency ratio sebesar 2,924 . Hal ini berbanding terbalik dengan Sugianti dkk (2014) yang menyatakan bahwa wilayah yang semakin dekat dengan struktur kelurusan struktur geologi memiliki pengaruh terhadap pergeseran retakan pada batuan. Namun, melihat fakta di atas dapat dimungkinkan bahwa patahan yang berada di daerah penelitian belum memunculkan gerakan aktif yang dapat memicu terjadinya kejadian tanah longsor.

\section{h. Batuan Geologi}



Gambar 10. Grafik Kumulatif Batuan Geologi

Berdasarkan Gambar 10 dapat diketahui bahwa pada faktor batuan geologi, kelas terrestrial alluvium merupakan kelas yang paling memengaruhi kejadian tanah longsor. Terrestrial alluvium tersusun dari material abu vulkanik bersifat kedap air dan menjadi licin saat hujan, sehingga lapisan ini dapat bertindak sebagai bidang luncur terhadap batuan breksi dan tanah yang terbentuk di atasnya. Dengan demikian, cukup wajar jika pada batuan geologi ini banyak terjadi proses longsor. Selain itu, terrestrial alluvium juga tersusun dari banyak material sedimen berumur tersier. Hal ini senada dengan Barus (1999) yang menyatakan bahwa hubungan litologi dengan longsor terlihat jelas di daerah dimana longsor banyak berasal dari batuan sedimen.

\section{Hasil Faktor Pengkondisi Tanah Longsor Yang Dominan Pada Kerentanan Tanah Longsor}

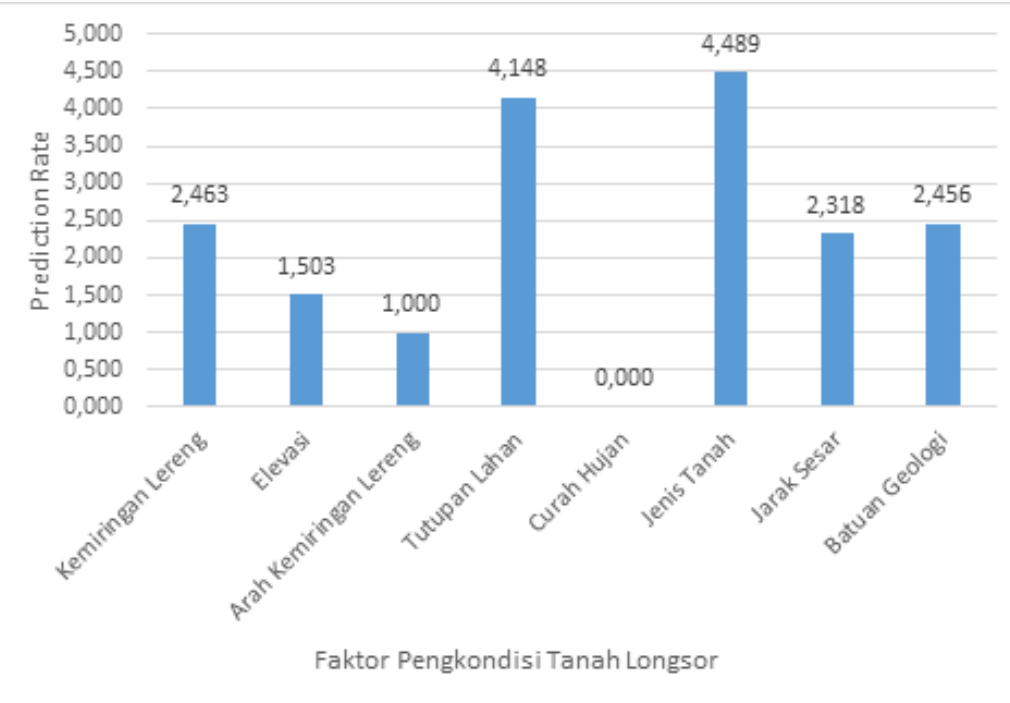

Gambar 11. Grafik Prediction Rate Faktor Pengkondisi Tanah Longsor 
Berdasarkan Gambar 11, terdapat 7 faktor yang dapat dianggap sebagai faktor pengkondisi tanah longsor yang dominan pada kerentanan tanah longsor. Faktor tersebut adalah kemiringan lereng, elevasi, arah kemiringan lereng, tutupan lahan, jenis tanah, jarak sesar, dan batuan geologi dikarenakan ketujuh faktor tersebut memiliki nilai PR (Prediction Rate). Jika dikaitkan dengan kualitas data, faktor curah hujan menggunakan 5 titik Stasiun Klimatologi saja, antara lain Stasiun Klimatologi Bandung, Bogor, Citeko, Kertajati, dan Penggung. Lokasi dari kelima titik Stasiun Klimatologi tersebut sangat berjauhan dan dipaksakan untuk dapat dilakukan perhitungan curah hujan di daerah penelitian. Menurut Keefer dan Wilson (1981), untuk melihat dan memodelkan pengaruh curah hujan pada potensi terjadinya longsor secara baik, digunakan data curah hujan dengan cakupan wilayah luas dan real time. Apabila dilihat teknologi satelit sekarang ini, salah satu satelit dengan cakupan wilayah luas dan real time yaitu TRMM/TMPA. Hal ini dilakukan untuk menambah kepastian data curah hujan yang akan dianalisis pada citra satelit yang digunakan. Berkaitan dengan faktor pengkondisi tanah longsor yang dominan, ketujuh faktor tersebut selanjutnya digunakan untuk zonasi kerentanan tanah longsor di Kabupaten Bandung Barat.

\section{Hasil Zonasi Kerentanan Tanah Longsor di Kabupaten Bandung Barat}

Zonasi kerentanan tanah longsor di Kabupaten Bandung Barat dilakukan dengan memasukkan 7 faktor pengkondisi tanah longsor yang dominan ke dalam proses pengolahan data. Pada proses ini, resolusi dari setiap faktor telah seragam yaitu $20 \mathrm{~m}$, hal ini sesuai dengan pendapat ESRI (2019) yang menyatakan bahwa apabila akan menggabungkan peta dengan resolusi yang berbeda, maka harus menyamakan ukuran pixel pada semua data yang digunakan agar diperoleh hasil yang optimal.

Hasil zonasi kerentanan tanah longsor selanjutnya diklasifikasikan menjadi 5 kelas, yaitu tidak rentan, sedikit rentan, cukup rentan, rentan, dan sangat rentan. Klasifikasi tersebut dilakukan dengan menggunakan metode natural breaks (jenks). Menurut ESRI (2010), metode klasifikasi natural breaks (jenks) berusaha untuk mengurangi variansi dalam kelas dan memaksimalkan variansi antar kelas. Gambar 12 merupakan hasil zonasi kerentanan tanah longsor di Kabupaten Bandung Barat.

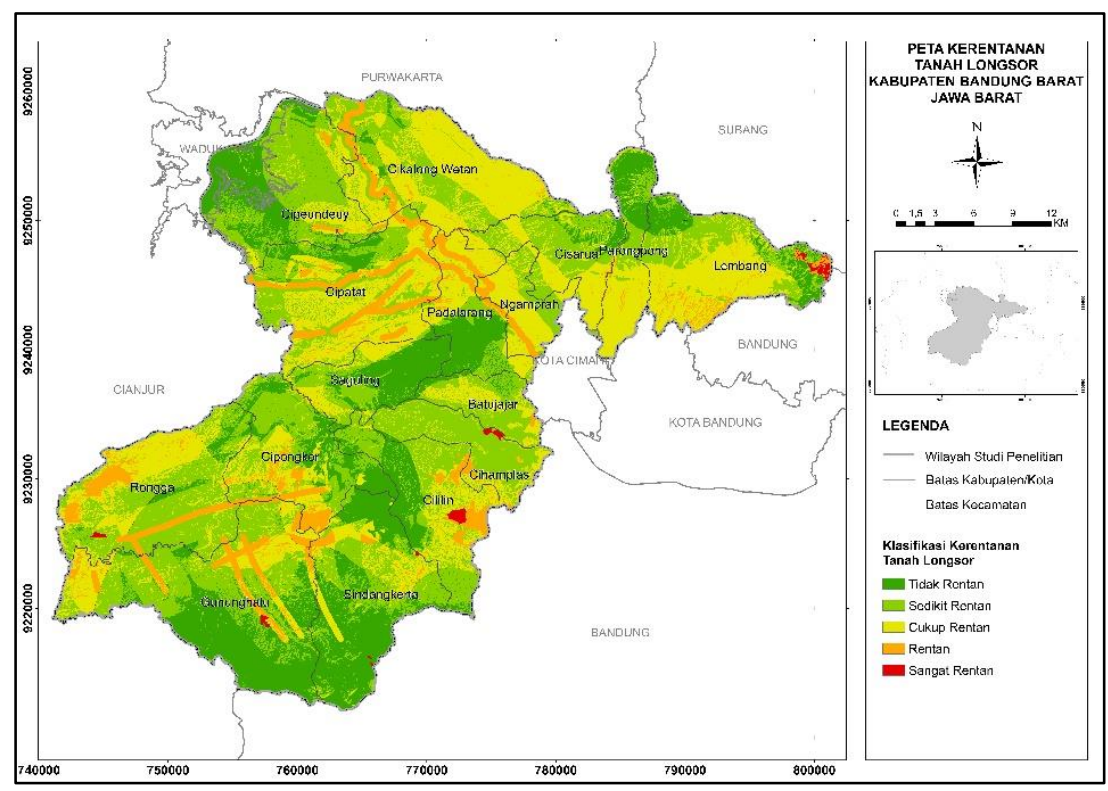

Gambar 12. Peta Kerentanan Tanah Longsor Kabupaten Bandung Barat

Berdasarkan hasil zonasi diperoleh informasi bahwa 21,49\% wilayah Kabupaten Bandung Barat termasuk dalam klasifikasi tidak rentan, 38,56\% sedikit rentan, 31,53\% cukup rentan, $8 \%$ rentan, dan $0,43 \%$ sangat rentan seperti yang ditunjukkan pada Tabel 1. Kemudian, berdasarkan Tabel 2 dapat diketahui bahwa Desa Suntenjaya merupakan desa yang memiliki luas wilayah terbesar yang termasuk dalam zona sangat rentan di Kabupaten Bandung Barat yaitu seluas 2,27 km2. 
Tabel 1. Luas Wilayah Pada Zonasi Kerentanan Tanah Longsor

\begin{tabular}{|c|c|c|c|}
\hline Data Layers & Class & Area $\mathbf{K M}^{2}$ & Percentage (\%) \\
\hline \multirow{5}{*}{ Longsor } & Tidak Rentan & 278,78 & 21,49 \\
\hline & Sedikit Rentan & 500,21 & 38,56 \\
\hline & Cukup Rentan & 409,03 & 31,53 \\
\hline & Rentan & 103,74 & 8,00 \\
\hline & Sangat Rentan & 5,55 & 0,43 \\
\hline \multicolumn{2}{|c|}{ Total } & 1297,32 & 100 \\
\hline
\end{tabular}

Tabel 2. Wilayah Pada Zonasi Sangat Rentan

\begin{tabular}{llc}
\hline \multicolumn{1}{c}{ Kecamatan } & \multicolumn{1}{c}{ Desa } & Area KM \\
\hline Rongga & Cicadas & 0,39 \\
\hline Gununghalu & Gununghalu & 0,44 \\
\hline \multirow{3}{*}{ Sindangkerta } & Mekarwangi & 0,10 \\
\cline { 2 - 3 } & Mekarwangi & 0,08 \\
\cline { 2 - 3 } & Buninagara & 0,09 \\
\hline \multirow{3}{*}{ Cililin } & Rancapanggung & 0,03 \\
\cline { 2 - 3 } & Mukapayung & 1,21 \\
\cline { 2 - 3 } Cihampelas & Kidangpananjung & 0,21 \\
\cline { 2 - 3 } & Citapen & 0,57 \\
\hline Batujajar & Cihampelas & 0,09 \\
\hline Lembang & Batujajar Barat & 0,07 \\
\hline
\end{tabular}

Jika dilihat secara keseluruhan, 11 Desa dalam 7 Kecamatan pada Tabel 2 dipengaruhi oleh beberapa karakteristik fisik yang mendominasi di wilayah tersebut, seperti yang ditunjukkan pada Tabel 3. Berdasarkan Tabel 3, dapat diketahui bahwa karakteristik-karakeristik tersebut yang mengakibatkan sejumlah wilayah di atas tergolong tidak aman terhadap kejadian tanah longsor.

Tabel 3. Karakteristik Fisik terhadap Kepekaan Kejadian Tanah Longsor

\begin{tabular}{ccc}
\hline $\begin{array}{c}\text { No } \\
.\end{array}$ & Karakteristik Fisik & Kepekaan Kejadian Tanah Longsor \\
\hline 1 & Kemiringan Lereng 40-50 & Peka terhadap kejadian tanah longsor \\
\hline 2 & Didominasi Semak/Belukar dan Pemukiman & Peka terhadap kejadian tanah longsor \\
\hline 3 & Berada Pada Tanah Litosol dan Latosol & Peka terhadap erosi \\
\hline 4 & Berada Pada Batuan Terrestrial Alluvium & Peka terhadap erosi \\
\hline
\end{tabular}

\section{Hasil Uji Akurasi Metode Analisis ROC (Receiver Operating Characteristics)}

Pengujian akurasi peta kerentanan tanah longsor yang dihasilkan pada penelitian ini menggunakan metode analisis ROC. ROC adalah salah satu metode yang digunakan untuk mengetahui keakuratan model prediksi yang dihasilkan dari frequency ratio. Metode analisis ini memberikan hasil berupa kurva ROC dan AUC seperti yang ditunjukkan pada Gambar 13. 


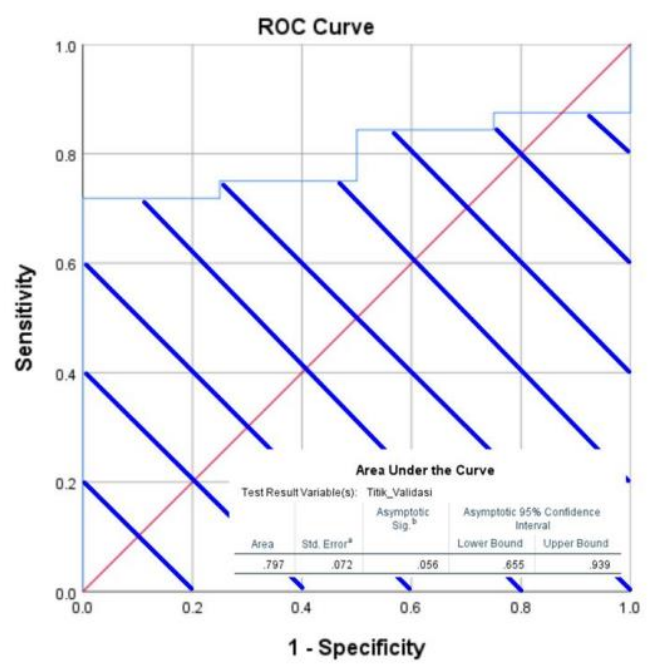

Gambar 13. Hasil Kurva ROC dan Nilai AUC

Berdasarkan Gambar 13, kurva ROC merupakan hubungan antara indeks Sensitivity dan 1-Specificity yang tiap titiknya menunjukkan tingkat kemampuan frequency ratio dalam memprediksi kejadian longsor. Tingkat keakuratan tinggi apabila kurva ROC yang dihasilkan bernilai mendekati 1 atau disebut juga perfect classification. Keakuratan frequency ratio dapat dilihat dari AUC pada kurva yang menunjukkan akurasi 0,797 atau $79,7 \%$.

\section{Kesimpulan}

Pemetaan kerentanan tanah longsor di Kabupaten Bandung Barat, Provinsi Jawa Barat dengan metode frequency ratio menyatakan bahwa faktor pengkondisi tanah longsor yang memengaruhi kerentanan tanah longsor yaitu kemiringan lereng, elevasi, arah kemiringan lereng, tutupan lahan, jenis tanah, jarak sesar, dan batuan geologi. Hasil peta kerentanan tanah longsor menunjukkan bahwa 21,49\% wilayah di Kabupaten Bandung Barat termasuk dalam klasifikasi tidak rentan, 38,56\% sedikit rentan, 31,53\% cukup rentan, $8 \%$ rentan, 0,43\% sangat rentan. Diketahui bahwa klasifikasi sangat rentan mencakup 11 Desa dan 7 Kecamatan. Hasil uji akurasi zonasi kerentanan tanah longsor menggunakan metode frequency ratio berdasarkan metode analisis ROC dianggap termasuk akurasi yang baik $(>50 \%)$, yaitu sebesar $79,7 \%$. Hasil ini dapat dinyatakan bahwa metode frequency ratio dapat diterapkan di Kabupaten Bandung Barat.

\section{Ucapan Terima kasih}

Ucapan terima kasih yang sebesar-besarnya disampaikan kepada Bapak dan Ibu Dosen Teknik Geodesi ITENAS Bandung serta rekan-rekan Ekstensi UGM yang telah membantu dalam penelitian ini.

\section{Daftar Pustaka}

Abe, K., \& Ziemer, R. (1991). Effect of Tree Roots on Shallow-Seated Landslides. Proceedings of the IUFRO Technical Session on Geomorphic Hazards in Managed Forests.

Arifin. (2006). Implementasi Penginderaan Jauh dan SIG untuk Inventarisasi Daerah Rawan Bencana Longsor (Provinsi Lampung). Jurnal Penginderaan Jauh dan Pengolahan Citra Digital, 77-86.

Arsyad, S. (2010). Konservasi Tanah dan Air. Bogor: IPB Press.

Barus, B. (1999). Pemetaan Bahaya Longsoran Berdasarkan Klasifikasi Statistik Peubah Tunggal Menggunakan SIG: Studi Kasus Daerah Ciawi-Puncak-Pacet, Jawa Barat. Jurnal Ilmu Tanah dan Lingkungan, 2(1):7-16.

Conforti, M. (2012). Application and Validation of Bivariate GIS-Based Landslide Suspectibility Assessment for the Vitravo River Catchment. Nat. Hazards, 127-141.

Corsini, A. (2009). Coupling Geomorphologic Field Observation and LIDAR Derivates to Map Complex Landslide. Proceeding of The Landslide Processes Conference. Direktorat Geologi dan Tata Lingkungan. (2009). Gerakan Tanah di Indonesia. Jakarta: Dirjen Pertambangan Umum. http://lib.geo.ugm.ac.id/ojs/index.php /jbi/article/viewFile/545/518 diakses pada tanggal 1 Agustus 2020. 
ESRI. (2010). Natural Breaks (Jenks). http://resources.esri.com/help/9.3/arcgisdesktop/com/gptoolref/Environment Settings/natural_breaks.htm diakses pada tanggal 1 Agustus 2020.

ESRI. (2019). Cell Size. http://resources.esri.com/help/9.3/arcgisdesktop/com/gptoolref/EnvironmentSettings/cell size.htm diakses pada tanggal 1 Agustus 2020.

Gerrard, A. J. (1981). Soils and Landforms: An Integration of Geomorphology and Pedology. London: George Allen and Unwin.

Keefer, D. R., \& Wilson, R. C. (1981). Predicting Global Landslide Spatiotemporal Distribution: Integrating Landslide Susceptibility Zoning Techniques and Real-Time Satellite Rainfall Estimates. International Journal of Sediment Research.

Polykretis, C. (2014). A Comparative Study of Landslide Suspectibility Mapping Using Landslide Suspectibility Index and Artificial Neural Networks in the Krios River and Krathis River Catchments. Geol. Environ.

PUPR. (2015). Rencana Program Investasi Jangka Menengah Kabupaten Bandung Barat 2015-2019. Jakarta: SIPPA Ciptakarya.

PVMBG. (2018). Publikasi Peringatan Dini Gerakan Tanah. https://vsi.esdm.go.id/ diakses pada tanggal 20 Mei 2020.

Tien Bui, D. (2011). Landslide Suspectibility Analysis in the Hoa Binh Province of Vietnam Using Statistical Index and Logistic Regression. Nat. Hazards.

Sadisun, A. I. (2005). Usaha Pemahaman Terhadap Stabilitas Lereng dan Longsoran Sebagai Langkah Awal Dalam Mitigasi Bencana Longsoran. Bandung: Departemen Teknik Geologi Institut Teknologi Bandung

Sugianti, K. (2014). Pengklasan Tingkat Kerentanan Gerakan Tanah Daerah Sumedang Selatan Menggunakan Metode Storie. Riset Geologi dan Pertambangan. 